\title{
Tingkat Kerentanan Banjir Kota Sorong Papua Barat
}

\author{
Syaiful Maliki Arief ${ }^{1}$, Rima H S Siburian ${ }^{2}$, Wahyudi ${ }^{3}$ \\ Universitas Papua \\ ${ }^{2}$ r.siburian@unipa.ac.id
}

\begin{abstract}
Abstrak
Kota Sorong merupakan salah satu kota di Provinsi Papua Barat yang sering menghadapi masalah banjir. Namun seberapa luas daerah yang rentan terhadap kondisi ini, belum ada data mengenai hal tersebut. Untuk itu perlu dilakukan penelitian untuk mengetahui sebaran tingkat kerentanan bencana banjir di kota Sorong. Penelitian ini merupakan penelitian deskriptif menggunakan analisis dan sebaran pola tingkat kerentanan banjir dengan teknik analisa data menggunakan overlay, scoring, dan layout berdasarkan software Arc View 10.5. Hasil penelitian menunjukkan bahwa tingkat kerentanan banjir di Kota Sorong diklasifikasikan dalam 4 tingkat kerentanan banjir yang meliputi sangat rentan, rentan, kurang rentan, dan tidak rentan. Seluas 4, $53 \%$ wilayah kota Sorong tergolong sangat rentan terhadap banjir, rentan banjir seluas 33,65\% yang kurang rentan sebasar $42.11 \%$ dan daerah tidak rentan sebesar $19,71 \%$. Wilayah yang harus diwaspadai karena rentan dan sangat rentan banjir adalah seluas 38,18 \% meliputi Distrik Sorong Timur, Manoy, Sorong, Sorong Kota dan Sorong Barat. Daerah tersebut adalah pusat pemerintahan dan termasuk daerah padat pemukiman penduduk.
\end{abstract}

Kata kunci: Banjir, Kota Sorong, tingkat kerentanan.

\section{Pendahuluan}

Kota Sorong merupakan salah satu kota di wilayah Provinsi Papua Barat yang terletak berbatasan dengan pesisir pantai. Tipe iklim wilayah ini adalah termasuk tipe hutan hujan tropis dengan rata-rata curah hujan per bulan sebesar 262,41 mm Banyaknya hari hujan dalam setiap bulan antara 9-29 hari, dan kelembaban udara ratarata tercatat $84 \%$ dan suhu udara minimum di kota Sorong sekitar $23,1^{\circ} \mathrm{C}$ dan suhu udara maximum sekitar $33,7^{\circ} \mathrm{C}$ (Badan Meteorologi, Klimatologi dan Geofisika Sorong, 2017.) Tingginya curah hujan dan posisi kota Sorong ini menyebabkan kota Sorong rawan terkena banjir yang disebabkan kenaikan permukaaan air laut, maupun karena curah hujan yang tinggi.

Menurut IPCC (2007) (Intergovern-mental Panel on Climate Change) dalam 100 tahun terakhir telah terjadi peningkatan permukaan air laut setinggi 10-25 cm. Sementara kenaikan permukaan air laut ini telah terjadi sejak akhir abad ke-19 dan ratarata kenaikan permukaan air laut berkisar antara 10 dan $20 \mathrm{~cm}$ selama abad ke-20 ini. Diprediksi bahwa rata-rata permukaan air laut akan meningkat antara 9 dan $88 \mathrm{~cm}$ yang terjadi sejak tahun 1990 hingga tahun 2100 hal ini diakibatkan oleh peningkatan ratarata suhu global dunia yang berkisar antara $0,6 \pm 0,2^{\circ} \mathrm{C}$ (Putuhena, 2011). Hal ini akan sangat dampak pada: peningkatan risiko banjir dan gelombang pasang; erosi pantai dan peningkatan sedimentasi; perubahan kecepatan aliran sungai; meningkatnya gelombang laut; dan meningkatnya keamblesan (subsidence) tanah. Dampak lainnya adalah dampak ekologis berupa hilang/berkurangnya wilayah genangan (wetland) di wilayah pesisir. 
Gafur (2008) mengungkapkan bahwa potensi banjir di kota Sorong pada umumnya disebabkan oleh aliran permukaan yang berasal dari Sub DAS Malanu dan Sub DAS Bateng Kali Empat. Potensi banjir di sub DAS Bateng Kali Empat ini akan semakin meningkat volumenya disebabkan oleh peningkatan jumlah pemukiman pada kawasan ini, serta diperberat oleh kondisi hidrologi yang buruk, bahkan saluran dan sistem drainase kota yang belum memadai sehingga menjadikan pusat kota Sorong menjadi kawasan yang paling rentan banjir. Namun seberapa besar dan pada kawasan mana saja di kota Sorong yang merupakan daerah rentan banjir, perlu dilakukan penelitian lebih mendalam. Untuk itu penelitian ini dilakukan guna mendapatkan informasi mengenai penyebaran daerah dengan tingkat kerentanan banjir di kota Sorong, untuk mengantisipasi bahaya banjir yang dapat berdampak bukan saja kepada kerugian materi tetapi juga nyawa manusia.

\section{METODE PENELITIAN}

Penelitian ini dilaksanakan di kota Sorong, Papua Barat pada bulan Februari dan Maret 2018 melalui dua tahap yakni penelitian lapangan dan analisis Sistem Informasi Geografi (SIG) yang dilakukan di laboratorium Universitas Papua, Manokwari.

Alat yang digunakan dalam penelitian ini adalah komputer, scanner, software GIS, microsoft exel, kamera, printer. Sedangkan bahan yang digunakan dalam penelitian ini merupakan data spasial dan tabular yang meliputi data fisik dan data sosial, yaitu:

1. Peta Rupa Bumi (RBI) Kota Sorong skala 1:150.000.

2. Peta Administrasi Kota Sorong skala 1:150.000.

3. Peta Rencana Tata Ruang Wilayah (RTRW) Kota Sorong skala 1:150.000

4. Peta Jenis Tanah Kota Sorong skala 1:150.000 .

5. Peta Topografi Kota Sorong skala 1:150.000 .

6. Peta Pemanfaatan Lahan Kota Sorong skala 1:150.000

7. Data Curah Hujan dan Hari Hujan Kota Sorong 10 tahun terakhir

8. Data Statistik Kota Sorong dalam Angka

9. Buku Rencana Tata Ruang Wilayah Kota Sorong

Penelitian ini menggunakan metode deskriptif dengan analisis komparatif yaitu untuk mengungkapkan suatu fenomena keadaan alam yang berpotensi menyebabkan terjadinya banjir dan kemudian dilihat tingkat bahaya banjir tersebut dengan memanfaatkan Sistem Informasi Geografi (SIG). SIG digunakan sebagai piranti/alat analisis yang bersifat keruangan/georeference. Penentuan kerentanan bencana menggunakan metode skoring dan pembobotan. Semua variabel diberi skor dan dibobot. Pembuatan peta kerentanan dilakukan dengan menumpangsusunkan (overlay) beberapa peta yang dianggap paling berpengaruh terhadap terjadinya banjir di kota Sorong.

\section{HASIL DAN PEMBAHASAN}

Penentuan kerentanan banjir dilakukan melalui beberapa langkah, berdasarkan pada data yang telah diperoleh sebelumnya. Data yang diperoleh merupakan data spasial yang berbentuk file jpeg..

Data-data yang digunakan sebagai parameter dalam penentuan tingkat kerentanan banjir pada penelitian ini antara lain, kemiringan lereng (slope), tekstur tanah (dalam kaitannya infiltrasi tanah), dan Topografi (ketinggian tempat). Masing-masing parameter dinilai dengan cara penggolongan dalam kelas yang sesuai dengan besarnya pengaruh terhadap tingkat kerentanan banjir di daerah penelitian. Parameter-parameter 
yang mempunyai tipe pengaruh yang besar terhadap terjadinya banjir diberi nilai yang besar, demikian juga sebaliknya parameter dengan tipe pengaruh yang kecil terhadap terjadinya banjir akan diberi nilai yang kecil.

Proses selanjutnya menurut Budiyanto (2002) dalam analisis peta tingkat kerentenan banjir dilakukan sistem tumpangsusun (overlay) dari parameter-parameter yang telah dinilai. Hasil analisis tumpang susun tersebut kemudian diklasifikasi dan hasilnya adalah peta yang berisi kelas/tingkat kerentanan banjir di Kota Sorong, kelas kerentanan banjir tersebut yaitu: kelas I (sangat rentan), kelas II (rentan), kelas III (kurang rentan), dan kelas IV (tidak rentan). Rincian mengenai luas dan persentase tingkat kerentanan banjir di kota Sorong disajikan dalam peta kerentanan Banjir Kota Sorong.

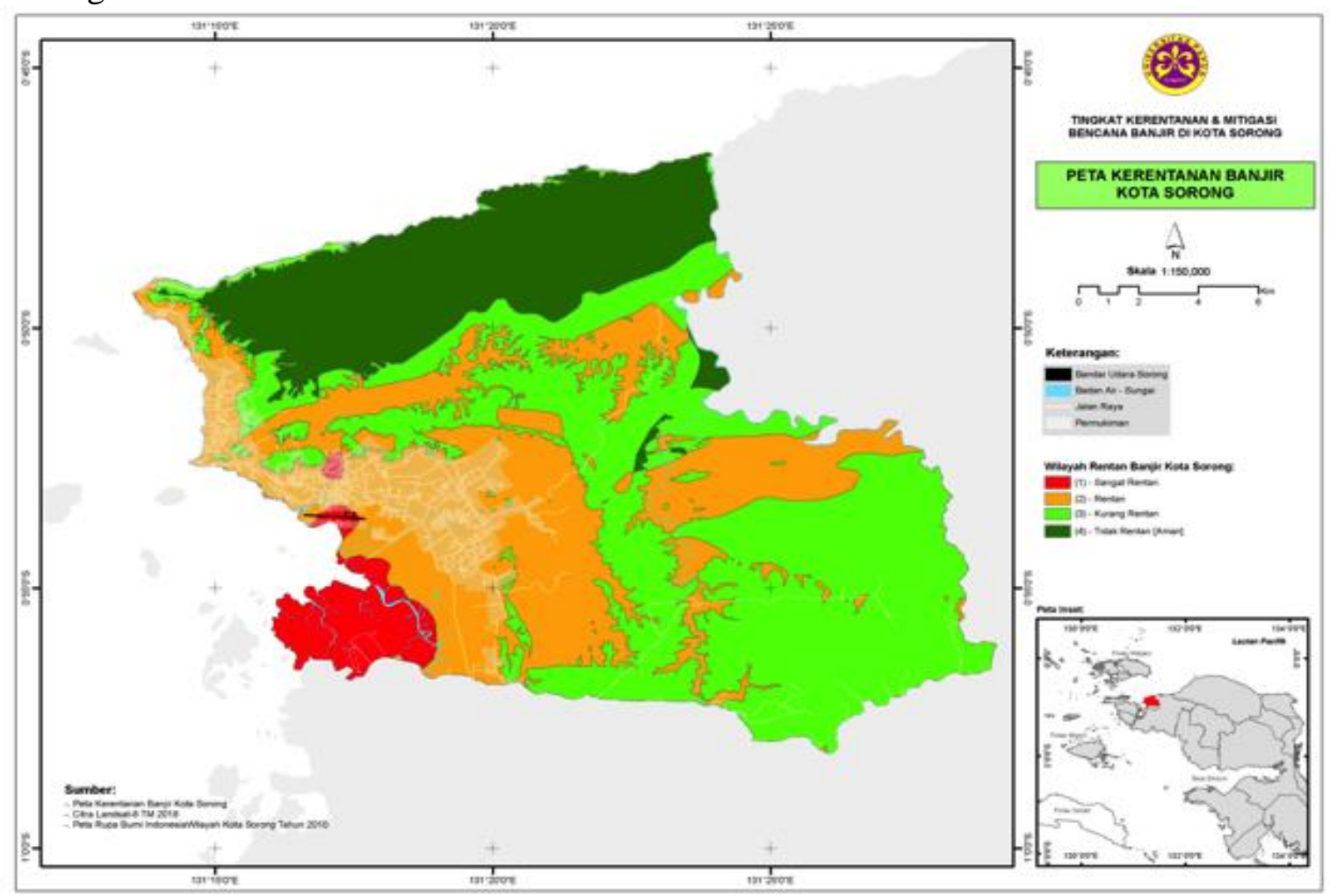

Gambar 1. Peta Kerentanan Banjir Kota Sorong

Dari analisis kerentanan banjir di kota Sorong daerah sangat rentan sebesar 4,53 $\%$ atau seluas 1.578,9 Ha. Sedangkan daerah yang rentan banjir seluas 33,65 \% atau seluas $11.728 \mathrm{Ha}$. Daerah yang digolongkan kurang rentan sebasar $42.11 \%$ atau seluas 14.675,3 Ha dan daerah yang tidak rentan sebesar 19,71\% atau sekitar 6.870 Ha. Daerah yang termasuk ke dalam daerah yang rentan dan sangat rentan banjir adalah daerah pusat kota yang terletak di daerah pesisir pantai dengan topografi datar dengan kelerang $0-2 \%$ dan ketinggian rendah yaitu dibawah 25 meter.

Kota Sorong yang terletak di pesisir pantai dengan lahan yang datar dikelilingi perbukitan berpotensi untuk menjadi tempat terakumulasinya air permukaan yang meluncur dari perbukitan. Hal ini jika tidak disertai dengan perencanaan dan pembuatan tata drainase kota yang baik akan menyebabkan tergenangnya air dan menjadi daerah yang rawan banjir.

Kota Sorong dilintasi oleh 8 sungai. Salah satu sungai yang terbesar yang melintas di tengah kota dikenal dengan nama Sungai Remu. Di Sungai Remu ini jika 


\section{Median Volume 11 Nomor 2 Bulan Juni 2019}

air pasang dapat digunakan sebagai lintasan perahu yang bermuara sampai di pesisir pantai kota Sorong.

Secara umum potensi banjir yang terjadi di kota Sorong diungkapkan oleh Gafur (2008) adalah merupakan akumulasi dari aliran permukaan masing-masing sub DAS dalam kawasan DAS Sungai Remu Kota Sorong. Kondisi topografi/ kemiringan lahan di hulu yang relatif lebih curam dan terjal sehingga aliran permukaan akan terakumulasi dengan cepat di hilir (kawasan pusat kota) dengan topografi Kota Sorong yang relatif datar. Diungkapkan pula bahwa sebagian besar wilayah kota terletak di pinggiran pantai dengan sebagiannya lahannya berupa rawa, sehingga elevasi muka air tanah cukup tinggi. Hal ini mengakibatkan daya tampung resapan sangat kecil terutama pada saat hujan. Kondisi ini makin buruk apabila air laut pasang. Adapun lokasi persebaran tersebut bila dipetakan seperti pada Gambar 2.

Terdapat lima Distrik yang mempunyai daerah yang sangat rentan banjir yaitu yang pertama adalah Distrik Klaurung seluas 1.255,6 ha atau 3,60 \% dari luas wilayah kota sorong. Kedua adalah Distrik Sorong Timur dengan luasan sebesar 145,8 ha atau $0,42 \%$ dari luas wilayah kota Sorong. Kemudian yang ke tiga adalah Distrik Manoi dengan luasan sebesar $122 \mathrm{Ha}$ atau sebesar 0,35 \% dari luas wilayah Kota Sorong. Distrik Sorong seluas 49,7 Ha atau sebesar 0,14 \% dari wilayah kota Sorong dan yang terakhir adalah Distrik Malaimsimsa sebesar 6,1 Ha atau sebesar 0,01 \%. Kelima Distrik tersebut terletak di daerah pesisir pantai dengan topografi datar dengan kelerang $0-2 \%$ dan ketinggian rendah yaitu dibawah $25 \mathrm{M}$ dengan demikian menyebabkan daerah tersebut sangat rentan terhadap banjir. Distrik-disrik tersebut terletak di pusat kota dan perdagangan serta merupakan tempat-tempat dengan pemukiman yang padat penduduk.

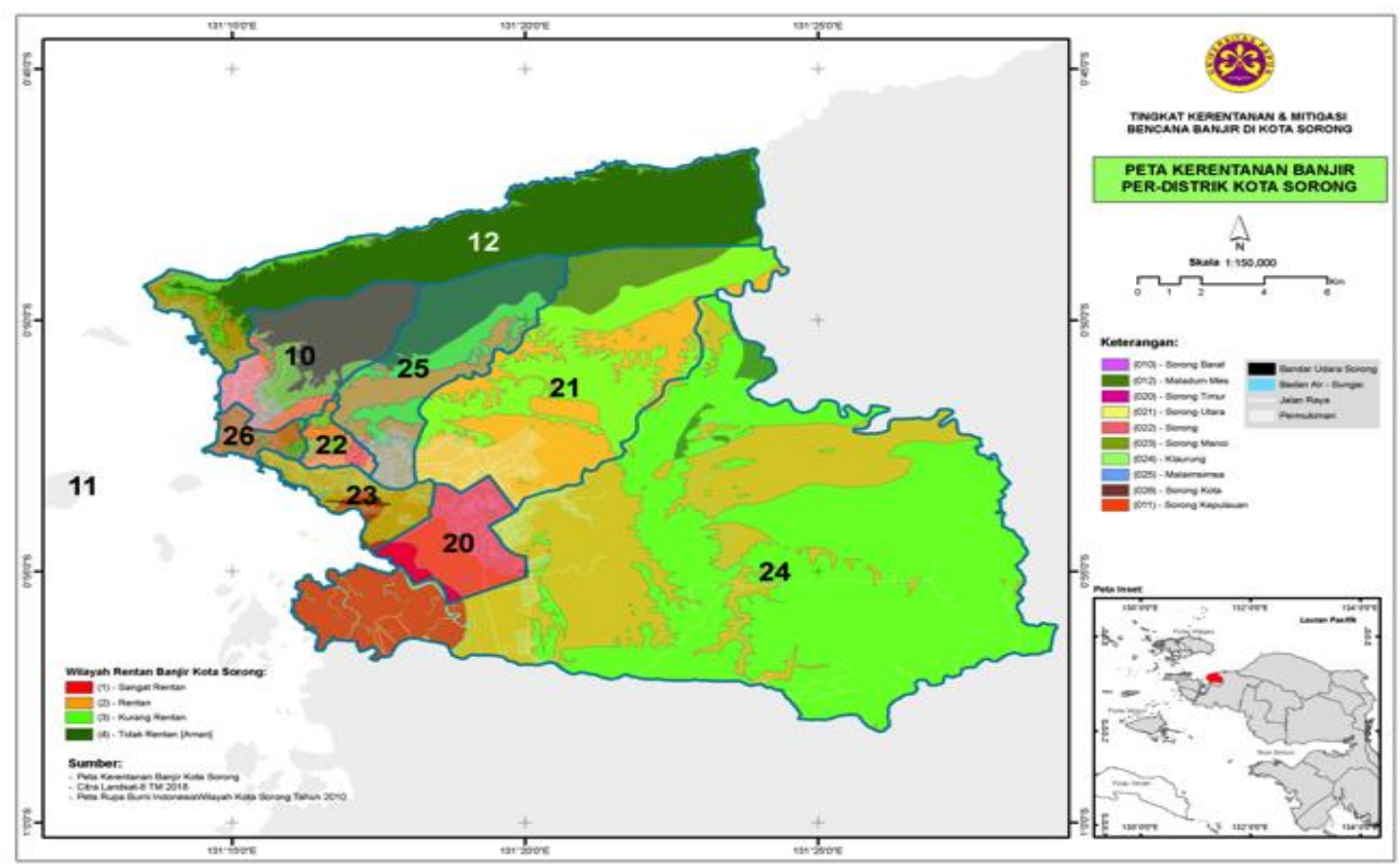

Gambar 2 Peta Kerentanan banjir Per Distrik- Kota Sorong.

Kota Sorong adalah kota yang sedang berkembang dengan kepadatan penduduk yang tinggi menyebabkan kebutuhan rumah sebagai hunian sangat tinggi dan 


\section{Median Volume 11 Nomor 2 Bulan Juni 2019}

pengalihan fungsi lahan sebagai perumahan hal ini jika tidak dikelola dengan baik akan mengakibatkan masalah banjir, Pengalihan lahan menjadi daerah permukiman menyebabkan banyak lahan yang awalnya tertutup vegetasi menjadi lahan terbangun tanpa vegetasi dengan penggunaan material beton (perkerasan). Hal ini menyebabkan air hujan yang jatuh akan menjadi aliran permukaan yang apabila terakumulasi di daerah hilir akan menyebabkan banjir. Hal ini sesuai dengan pendapat Somantri (2008) yang mengungkapkan bahwa penyebab banjir salah satunya adalah karena alih fungsi lahan pada suatu kawasan.

Seluruh Distrik di kota Sorong mempunyai daerah yang rentan terhadap banjir. Distrik yang terluas dikategorikan daerah rentan banjir adalah Distrik Klaurung yaitu sebesar 1.552 ha atau sebesar 15,93\%. Kemudian disusul oleh Distrik Sorong timur seluas $2.384,8 \mathrm{Ha}$ atau sebesar $6 \%$ dari luas wilayah kota Sorong.

\section{KESIMPULAN}

Hasil penelitian menunjukkan bahwa tingkat kerentanan dan bahaya banjir di Kota Sorong diklasifikasikan dalam 4 tingkat kerentanan banjir yang meliputi sangat rentan, rentan, kurang rentan, dan tidak rentan. Seluas 4, $21 \%$ wilayah kota Sorong tergolong sangat rentan terhadap banjir, rentan banjir seluas 33,65\% yang kurang rentan sebasar $42.11 \%$ dan daerah tidak rentan sebesar $19,71 \%$. Wilayah yang harus diwaspadai karena rentan dan sangat rentan banjir adalah seluas 45,48 \% meliputi Distrik Sorong Timur, Manoy, Sorong, Sorong Kota dan Sorong Barat. Daerah tersebut adalah pusat pemerintahan dan termasuk daerah padat pemukiman penduduk.

\section{DAFTAR PUSTAKA}

Badan Meteorologi, Klimatologi dan Geofisika Sorong, 2017. Kota Sorong.

Budiyanto, E 2002. Sistem Informasi Geografis Menggunakan ARC VIEW GIS. Penerbitan Andi, Yogyakarta.

Gafur, Muzna, A. 2008. Analisis Potensi banjir berdasarkan Aliran Permukaan pada DAS Remu Wilayah Kota Sorong Provinsi Papua Barat. Thesis Magister Pertanian Universitas Samratulangi. Manado.

IPCC. 2007. Climate change 2007, the physical Science Basis. Conteribution of working group I to the fourth Assesment report of the intergovernmental panel on climate change. United Kingdom and New York, USA: Cambridge University Press.

Putuhena. 2011. Perubahan iklim dan resiko bencana pada wilayah pesisir dan pulaupulau kecil. Prosiding seminar Nasional Pengembangan Pulau-pulau Kecil. Hal 287-298.

Sayogo, S. S., dkk. (2009). "Pemanfaatan Sistem Informasi Geografis Untuk Menganalisis Genangan Air Hujan", NEUTRON, VOL.9, NO.2

Somantri, L. (2008). "Pemanfaatan Teknik Penginderaan Jauh Untuk Mengidentifikasi Kerentanan dan Resiko Banjir”, Jurnal Gea, Jurusan Pendidikan Geografi, Vol.2, No.8. 